\title{
Cytotoxic and apoptotic effects of poly (maleic anhydride-co-vinyl acetate) drug carrier copolymer on MCF-7 and MDA-MB-231 breast cancer cells
}

\section{Bir illaç taşıyıcı kopolimer olan poly (maleik anhidrid-- ko-vinil asetat)'ın MCF-7 ve MDA-MB-231 meme kanser hücre hatlarında sitotoksik ve apoptotik etkisi}

\author{
Zeynep Deniz Şahin-İnan¹, Serap Şahin-Bölüikbaşı², Güilderen Karakuş ${ }^{3}$
}

Sivas Cumhuriyet University, Faculty of Medicine, Department of Histology-Embryology, Sivas, TURKEY

${ }^{2}$ Sivas Cumhuriyet University, Faculty of Pharmacy, Department of Biochemistry, Sivas, TURKEY

'Sivas Cumhuriyet University, Faculty of Pharmacy, Department of Pharmaceutical Chemistry, Sivas, Turkey

Corresponding author: Zeynep Deniz Şahin-İnan, MD, Sivas Cumhuriyet University, Faculty of Medicine, Department of Histology-Embryology, Sivas, TURKEY

E-mail: zinan@cumhuriyet.edu.tr

Received/Accepted: April 12,2019/September 27, 2019

Conflict of interest: There is not a conflict of interest.

\section{SUMMARY}

In recent years, copolymers are frequently used in many areas. The biocompatibility of any copolymer should be examined for practical application. One of these copolymers is Poly [(maleic anhydride) -co- (vinyl acetate) (MAVA), and the usage area of MAVA is quite limited. In this study, the cytotoxic effect of MAVA on MDA-MB-231 and MCF-7 human breast cancer cells was determined by MTT (3- (4,5-dimethylthiazol-2-yl) 2,5-diphenyltetrazolium bromide), and apoptotic cells are marked with DAPI staining. For this purpose, MDA-MB-231 and MCF-7 human breast cancer cells were incubated with different concentrations of MAVA $(1,10$, $50,80,100,200,300,500,800$, and $1000 \mu \mathrm{M})$ for $24 \mathrm{~h}, 48 \mathrm{~h}$, and $72 \mathrm{~h} . \mathrm{IC}_{50}$ values (concentration of the test compound to achieve $50 \%$ of cell death ) of MAVA in MDA-MB-231 and MCF-7 human breast cancer cells were determined $(n=9)$. According to our results, it was observed that MDA-MB231 breast cancer cells increased $24 \mathrm{~h}$ and $48 \mathrm{~h}$ after MAVA application compared to the control group and no significant change was observed after $72 \mathrm{~h}$ MAVA application. In MCF-7 cells, a significant decrease was observed $24 \mathrm{~h}$ and $48 \mathrm{~h}$ after MAVA application compared to control, and no significant changes were observed after 72 hours similar to MDA-MB231. Therefore, it could be suggested that MAVA showed a selective cytotoxic effect between MDA-MB-231 and MCF-7 breast cancer cells. DAPI staining showed that more apoptotic cells were found in MCF-7 cells after the MAVA application.

Keywords: Copolymer, poly(maleic anhydride-Co-vinyl acetate), MTT, MDA-MB-231, MCF-7, DAPI

\author{
Zeynep Deniz Şahin-İnan \\ (D) Serap Şahin-Bölükbaşi \\ (D) Gülderen Karakuş
}

ORCID IDs of the authors: D.Ş.İ. 0000-0002-0292-4448 S.Ş.B. $0000-0003-1057-2558$ G.K. 0000-0003-2596-9208 
Son yıllarda, kopolimerler birçok alanda sıklıkla kullanılmaktadır. Herhangibir kopolimerin pratik uygulaması için biyouyumluluğunun incelenmesi gerekmektedir. Bu kopolimerlerden biri Poly [(maleik anhidrit) -co- (vinil asetat)] (MAVA) 'dır ve kullanım alanı oldukça sınırlıdır. Bu çalışmada MAVA'nın MDA-MB-231 ve MCF-7 insan meme kanseri hücreleri üzerindeki sitotoksik etkisi, MTT (3- (4,5-dimetiltiazol-2-il) -2,5-difeniltetrazolyum bromür) ile belirlenmiş ve apoptoza giden hücreler DAPI boyaması ile işaretlenmiștir. Bu amaçla, MDA-MB-231 ve MCF-7 insan meme kanser hücreleri MAVA'nın farklı derişimleri ile (1-1000 $\mu \mathrm{M}), 24,48$ ve 72 saat inkübe edilmiştir. MAVA'nın, MDA-MB-231 ve MCF-7 insan meme kanseri hücrelerinde $\mathrm{IC}_{50}$ değerleri (hücre ölümünün\% 50 'sine ulaşmak için test bileşiğinin konsantrasyonu) belirlenmiştir ( $\mathrm{n}=9$ ). Elde ettiğimiz sonuçlara göre MDA-MB-231 meme kanseri hücrelerinin kontrol grubuna göre MAVA uygulamasından 24 saat ve 48 saat sonra arttı̆g 1 ve 72 saat MAVA uygulamasından sonra anlamlı bir değiş̧iklik olmadığı gözlendi. MCF-7 hücrelerinde, MAVA uygulamasından 24 saat ve 48 saat sonra kontrole kıyasla anlamlı bir azalma gözlendi ve 72 saat sonra MDA-MB-231'e benzer şekilde önemli bir değişiklik gözlenmedi. Bu nedenle MAVA'nın MDA-MB-231 ve MCF-7 meme kanseri hücreleri arasında seçici bir sitotoksik etki gösterdiği ileri sürülebilir. DAPI boyaması, MAVA uygulamasından sonra MCF-7 hücrelerinde daha fazla apoptotik hücre bulunduğunu göstermiştir.

Anahtar sözcükler: Kopolimer, poly(maleic anhydride-co-vinyl acetate), MTT, MDA-MB-231, MCF-7, DAPI

\section{INTRODUCTION}

Cancer incidence and mortality are rapidly growing worldwide. Breast cancer is the most commonly diagnosed cancer among women and is the leading cause of cancer death. Breast cancer worldwide is the second type of cancer with the most frequent mortality rate $(11 \%){ }^{1}$. Despite significant advances in the development of cancer drugs, cancer mortality continues to increase ${ }^{2-4}$. Currently, chemotherapy for breast cancer in clinical practice is usually accompanied by side effects and drug resistance, which result in therapeutic failure. Therefore, there is an urgent need to increase the effectiveness of novel agents with reduced side effects and the treatment of breast cancer. In vitro studies are an important tool for evaluating the mechanisms of toxicity caused by materials. Nowadays, the effects of many chemicals on breast cancer are investigated in vitro, and new strategies have been trying to be developed ${ }^{5,6}$. The present evidence shows the impressive results of therapy in the treatment of breast cancer by promoting cancer cell death and suppressing cancer metastasis ${ }^{7}$. Nowadays, many researchers are synthesizing new molecules for the treatment of breast cancer.

Maleic anhydride (MA) containing copolymers, such as MA-styrene, MA-vinyl acetate, or MAmethyl methacrylate is generally known as biocompatible (noncytotoxic, nonimmunogenic, and biodegradable) copolymers, having molecular weights below the renal excretion limit, and display biological activities ${ }^{8}$. Furthermore, MA copolymers formed with vinyl-based molecules could also be covalently coupled, by virtue of their functional groups, to generate polymer-drug conjugates ${ }^{9}$.
No research is available on the efficacy of MAVA in breast cancer cells. In this study, we aimed to investigate the effect of this formulation on breast cancer cell proliferation and apoptosis. For this purpose, the cytotoxicity and apoptotic effects of MAVA against MDA-MB-231 and MCF-7 cell lines were determined.

\section{MATERIAL AND METHODS}

\section{Materials}

Maleic anhydride (MA), methyl ethyl ketone (MEK), and benzoyl peroxide (BPO) were purchased from Merck (Germany). Ethyl alcohol was obtained from Smyras (Teknik, Turkey). Vinyl acetate (VA) and ethyl acetate were purchased from Sigma-Aldrich (USA).

\section{Preparation of MAVA copolymer}

Detail information of all of these synthesis process of MAVA could be followed in our previous study ${ }^{12}$. Briefly, drug carrier MAVA copolymer also known as poly(Maleic anhydride-co-Vinyl acetate), was synthesized by free-radical polymerization of maleic anhydride (MA) and vinyl acetate (VA), at a 1:1 molar ratio. Methyl ethyl ketone (MEK) was used as organic media presence of benzoyl peroxide (BPO) as the radical initiator for $24 \mathrm{~h}$ at $80^{\circ} \mathrm{C}^{8}$. Poly (vinyl acetate), was gently removed from the organic media by dissolving the reaction products in ethyl acetate for $24 \mathrm{~h}$. Then the products were dried in a vacuum incubator for $24 \mathrm{~h}$ at 55 ${ }^{\circ} \mathrm{C}{ }^{10}$.

\section{In vitro cytotoxic activity}

Cell culture; MCF-7 (HTB-22, human breast adenocarcinoma) and MDA-MB-231 (HTB-26, human breast adenocarcinoma), fetal bovine serum (FBS, 302021), penicillin and streptomycin (30-2300) were purchased from American Type Culture Collection (ATTC, Manassas, VA). Dulbecco's Modified Eagle's Medium (DMEM, D6429) were purchased from Sigma Aldrich. MCF-7 and MDA-MB-231 cells were grown in DMEM media containing 10\% (v/v) FBS, and 100 
Units $/ \mathrm{ml}$ penicillin and $100 \mu \mathrm{g} / \mathrm{ml}$ streptomycin in a $37^{\circ} \mathrm{C}$ humidified incubator with $5 \% \mathrm{CO}_{2}$. Cells were passaged at $70-80 \%$ confluence, about twice a week by trypsinization.

Cytotoxicity assay; The cytotoxic activities of MAVA were evaluated using the MTT assay on MDA-MB-231 and MCF-7 cells ${ }^{11}$. A stock solution of the MAVA was prepared in water. MDA-MB-231 and MCF-7 cells were seeded into 96-well plates at a density of $1 \times 10^{5}$ cells/well. After for $24 \mathrm{~h}$, the cells were treated with various concentration of MAVA $(1,10,50,80,100,200$, $300,500,800$, and $1000 \mu \mathrm{M})$, in $5 \% \mathrm{CO}_{2}$, at $37^{\circ} \mathrm{C}$, for $24 \mathrm{~h}, 48 \mathrm{~h}$, and $72 \mathrm{~h}$. The control wells contained cells with media. At the end of the time period, $10 \mu \mathrm{L} /$ well MTT was added, and the cells were incubated for $2 \mathrm{~h}$ at $37^{\circ} \mathrm{C}$ in $5 \% \mathrm{CO}_{2}$. After removal of the medium and MTT, the purple-blue precipitated crystals were dissolved in $100 \mu \mathrm{L}$ of DMSO (Sigma, St. Louis, MO). The absorbance was read at $570 \mathrm{~nm}$ an ELISA (Biotek, Epoch, USA). Evaluation is based on means from at least three independent experiments, each comprising three replicates per concentration level. Cytotoxic effects of MAVA were determined the dose-response curves were fitted by means of GraphPad Prism 7 (GraphPad Software, San Diego, CA, USA).

DAPI (4',6-diamidino-2-phenylindole, dihydrochloride) staining

The 4',6-diamidino-2-phenylindole (DAPI, Sigma, St. Louis, MO) is a fluorescent stain that binds strongly to adenine thymine-rich regions in DNA. It is used vastly in fluorescence microscopy. The effect of MAVA on MDA-MB-231 and MCF-7 cells was investigated. The cells were seeded, and after incubation for $24 \mathrm{~h}$ at $37^{\circ} \mathrm{C}$, the MDA-MB-231 and MCF-7 cells were treated with $\mathrm{IC}_{50}$ concentration of MAVA with at $24 \mathrm{~h}, 48 \mathrm{~h}$, and 72 h. After $24 \mathrm{~h}, 48 \mathrm{~h}$ and $72 \mathrm{~h}$ incubation, the MDA-MB231 and MCF-7 cells were washed three times with PBS and fixed with fresh $4 \%$ paraformaldehyde for $50 \mathrm{~min}$ at $25{ }^{0} \mathrm{C}$. The MDA-MB-231 and MCF-7 cells were subsequently stained with DAPI solution. After incubation for 2-3 min, cells were visualized under a fluorescence microscope (Olympus BX51, Japan) at 40× magnification with an excitation filter at $540 \mathrm{~nm}^{13}$.

\section{Statistical analysis}

All experiments were carried out in triplicates and results are expressed as means \pm SEM. Data were analyzed using one-way analysis of variance and differences were considered significant at $\left({ }^{*} p<0.05\right.$ vs control, $* * p<0.0001$ vs control, $\# \mathrm{p}<0.05$ vs MCF-7, $\# \# \mathrm{p}<0.0001$ vs $\mathrm{MCF}-7$ ).

\section{RESULTS}

MAVA were tested for their cytotoxic activities against MCF-7 and MDA-MB-231 breast cancer cell for $24 \mathrm{~h}, 48 \mathrm{~h}$ and $72 \mathrm{~h}$ using the MTT assay. MTT staining assesses the ability of cells to convert a soluble yellow tetrazolium salt into insoluble purple formazan crystals, which is facilitated by mitochondrial dehydrogenase enzymes. Graphs indicating the cytotoxic activities of MAVA on MDA-MB-231 and MCF-7 cells for $24 \mathrm{~h}, 48 \mathrm{~h}$, and $72 \mathrm{~h}$ are provided in Figure (1-3). The results were analyzed by cell viability graphics (Figure 1-3) which ranged up 1 to $1000 \mu \mathrm{M}$, suggesting that MAVA exhibited cytotoxic activity against cell lines to a different degree. As shown in Figure 1-3, cell viability varied obviously between different for a certain cell line. A comparison of cytotoxicity between the cell lines identifies compounds as selective anticancer agents. Results show that MAVA exhibits great selectivity between MDAMB-231 and MCF-7 breast cancer cells at $24 \mathrm{~h}$ and $48 \mathrm{~h}$ (Figure 1 and Figure 2). According to Figure 1-3, MAVA was found to be inactive against MDA-MB-231 cancer cells all time points but have moderate cytotoxic activity against MCF-7 breast cancer cells except $72 \mathrm{~h}$. It was observed that the MDA-MB-231 breast cancer cells increase $24 \mathrm{~h}$ and $48 \mathrm{~h}$ with MAVA application. Furthermore, it was observed that MAVA was possessed great selectivity for between human MCF-7 and MDAMB-231 breast cancer cells for $24 \mathrm{~h}$ and $48 \mathrm{~h}$. However, no difference was observed between the control group and cell lines at $72 \mathrm{~h}$. 


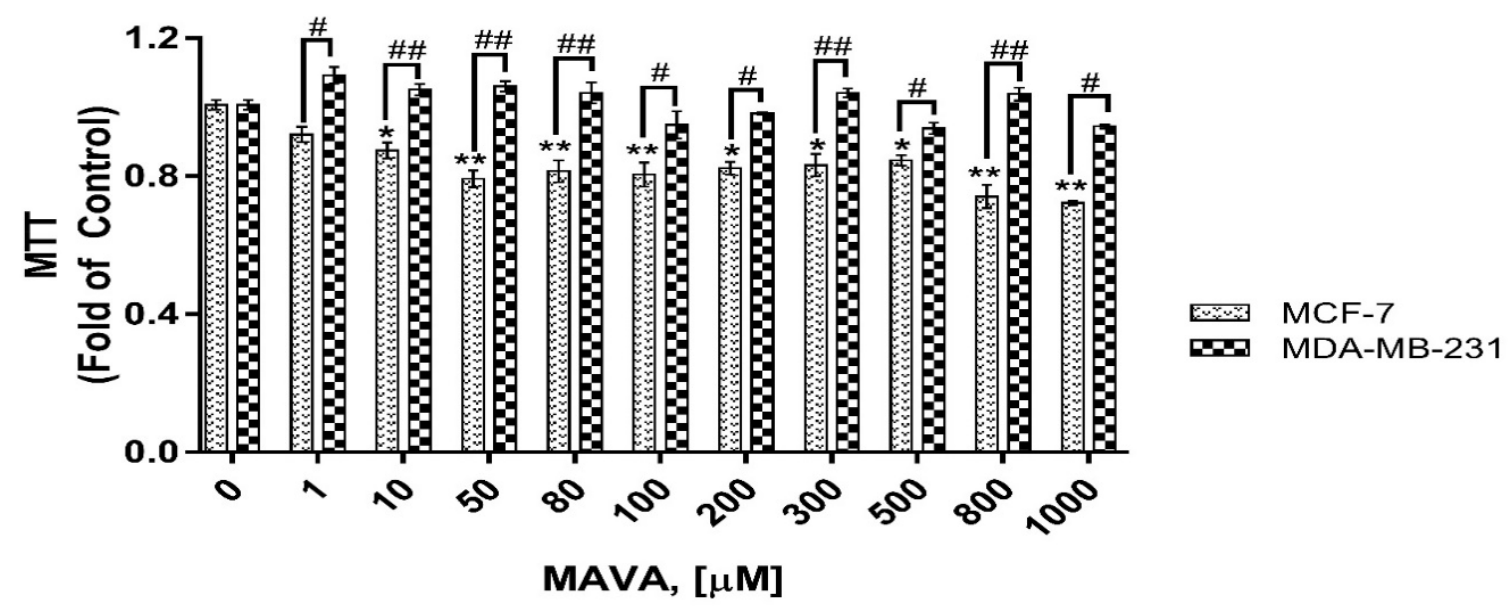

Figure 1: Cytotoxicity as determined by MTT assay. MCF-7 and MDA-MB-231 cells treated with 1 to 1000 $\mu \mathrm{M}$ of MAVA for $24 \mathrm{~h}$. Water treated cells were used as vehicle control. Data are representative of the mean \pm SEM of three separate experiments done in triplicate $(n=9)\left({ }^{*} \mathrm{p}<0.05\right.$ vs control, ${ }^{* *} \mathrm{p}<0.0001$ vs control, ${ }^{\#} \mathrm{p}<0.05$ vs MCF-7, ${ }^{\#} \mathrm{p}<0.0001$ vs MCF-7).

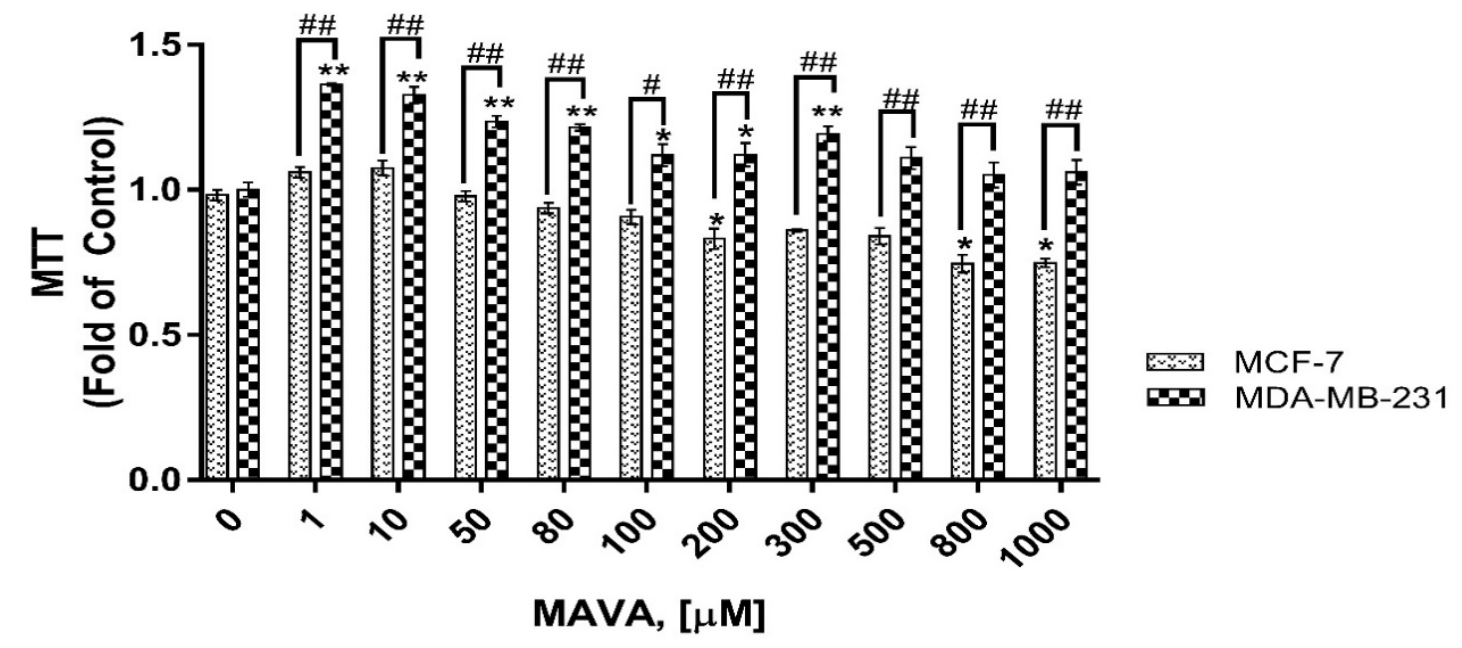

Figure 2: Cytotoxicity as determined by MTT assay. MCF-7 and MDA-MB-231 cells treated with 1 to 1000 $\mu \mathrm{M}$ of MAVA for $48 \mathrm{~h}$. Water treated cells were used as vehicle control. Data are representative of the mean \pm SEM of three separate experiments done in triplicate $(n=9)\left(* p<0.05\right.$ vs control, ${ }^{*} * p<0.0001$ vs control, ${ }^{\#} \mathrm{p}<0.05$ vs MCF-7, ${ }^{\#} \mathrm{p}<0.0001$ vs MCF-7). 


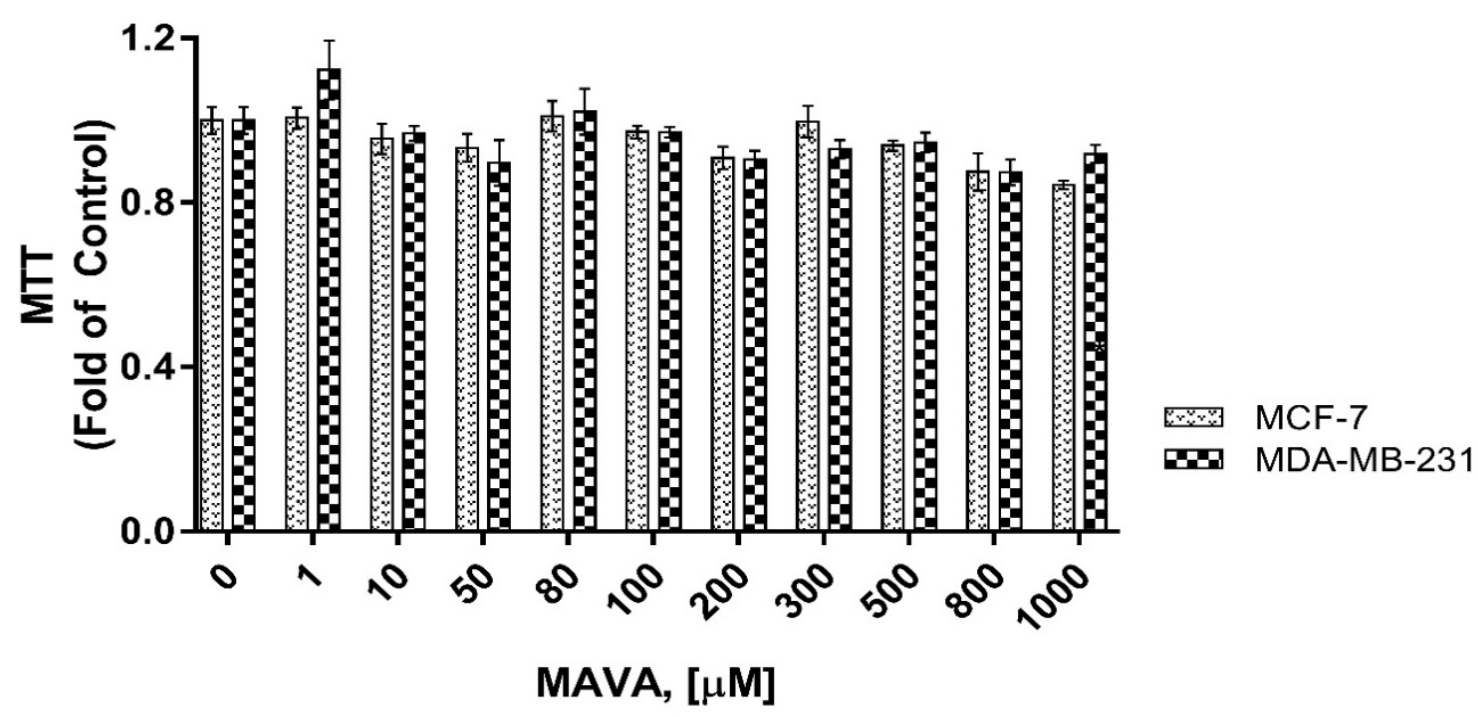

Figure 3: Cytotoxicity as determined by MTT assay. MCF-7 and MDA-MB-231 cells treated with 1 to 1000 $\mu \mathrm{M}$ of MAVA for $72 \mathrm{~h}$. Water treated cells were used as vehicle control. Data are representative of the mean \pm SEM of three separate experiments done in triplicate $(n=9)$.

In order to confirm the occurrence of apoptosis morphologically, cells were stained with DAPI and visualized under a fluorescent microscope. Untreated cells have normal nuclei (with a smooth nuclear membrane), whereas, it was observed that the apoptotic nuclei (concentrated or fragmented chromatin) in the treated cells with MAVA (Figure 4). Cells showed characteristic apoptotic changes, such as nuclear morphology, chromatin condensation, fragmentation of the nucleus, and the formation of apoptotic bodies. Apoptotic properties of MAVA were compared using the DAPI staining assay with controls at $24 \mathrm{~h}, 48 \mathrm{~h}$ and $72 \mathrm{~h}$ in MDAMB-231 and MCF7 cells as shown in Figure 4. It was observed that the number of apoptotic cells increased in both cell lines compared to the control group. In particular, more apoptotic cells were identified in the MCF-7 cell line than the MDAMB-231 cell line at $48 \mathrm{~h}$ and $72 \mathrm{~h}$.
Karakus and co-workers previously synthesized maleic anhydride copolymers by free-radical copolymerization named as: maleic anhydridevinyl acetate (MAVA) and structural characterizations were carried out by Fourier transform infrared (FTIR) and nuclear magnetic resonance $\left[{ }^{1} \mathrm{H}\right.$ NMR, ${ }^{13} \mathrm{C}$ NMR, and ${ }^{13} \mathrm{C}$-APT (attached-proton test)] spectrometry ${ }^{10}$. They have studied surface morphology by scanning electron microscopy (SEM). The solubility of the MAVA was examined in water along with twelve different organic solvents. Cytotoxicity of the MAVA was evaluated by using XTT test at $24 \mathrm{~h}$ on mouse fibroblast cell line (L929) ${ }^{10}$. They were found that MAVA had almost no toxicity at 62.5 to 500 $\mathrm{mg} / \mathrm{mL} \mu \mathrm{g} / \mathrm{ml}(342$ to $2700 \mu \mathrm{M})$ at $24 \mathrm{~h}^{10}$. 


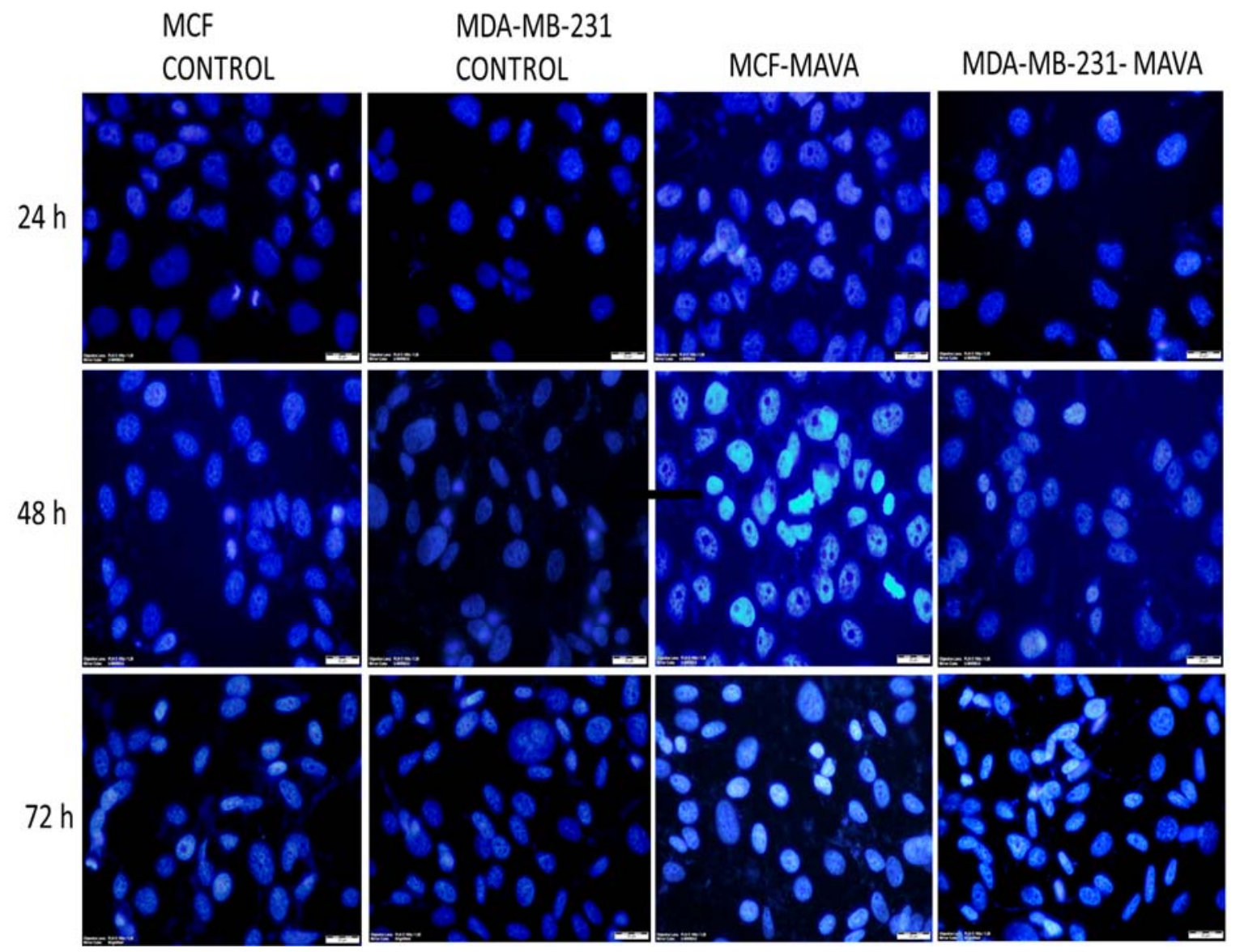

Figure 4: DAPI staining of MAVA on MDA-MB-231 and MCF7 cell lines at $24 \mathrm{~h}, 48 \mathrm{~h}$ and $72 \mathrm{~h}$.

\section{CONCLUSION}

This study summarizes the cytotoxic and apoptotic effect of MAVA, a copolymer, on the MDA-MB231 and MCF-7 breast cancer cell line. In our in vitro cytotoxic study suggests that MAVA showed higher cytotoxic activities against MCF-7 breast cancer cells than MDA-MB-231 at $24 \mathrm{~h}$ and $48 \mathrm{~h}$. It was determined that MAVA increased the number of apoptotic cells in both cell lines at 24, 48 and 72 hours, but in MCF 7 cells there were significantly more apoptotic cells compared to MDA-MB-231 cells especially at $48 \mathrm{~h}$ and $72 \mathrm{~h}$. It was observed that the activity of the MAVA varied depending on the types of cancer cells. In this study, MAVA has been observed to show selective toxicity specific to the MCF-7 cell line and to increase apoptosis. Bearing in mind the findings of the present study, when preffering the usage of MAVA in drug delivery systems, the cell type should be considered then advanced comprehensive studies should be designed.

\section{ACKNOWLEDGMENTS}

Cytotoxic activity studies were done at Sivas Cumhuriyet University Advanced Technology Application and Research Center (SCUTAM). This work was supported by the Sciences Research Projects Foundation of Cumhuriyet University (Project No: F258).

\section{REFERENCES}

1. Bray F, Ferlay J, Soerjomataram I, Siegel RL, Torre LA, Jemal A. Global cancer statistics 2018: GLOBOCAN estimates of incidence and mortality worldwide for 36 cancers in 185 countries CA. Cancer J Clin 2018; 68(6): 394424.

2. Liang AL, Qian HL, Zhang TT, et al. Bifunctional fused polypeptide inhibits the growth and metastasis of breast cancer. Drug Des Devel Ther. 2015; 9:5671-86.

3. Miao J, Du YZ, Yuan H, Zhang XG, Hu FQ. Drug resistance reversal activity of anticancer drug-loaded solid lipid nanoparticles in multidrug resistant cancer cells. Colloids Surf B Biointerfaces. 2013, 110: 74-80. 
4. Cabeza L, Ortiz R, Arias JL, et al. Enhanced antitumor activity of doxorubicin in breast cancer through the use of poly(butyl cyanoacrylate) nanoparticles. Int $\mathrm{J}$ Nanomedicine. 2015;13(10):1291-306.

5. Cancer Genome Atlas, Network Comprehensive molecular portraits of human breast tumors. Nature 490 (7418): 61-70.2012 DOI: 10.1038 /nature11412

6. Shargh VH, Hondermarck H, Liang $M$. Antibody-targeted biodegradable nanoparticles for cancer therapy. Nanomedicine (Lond). 2016;11(1):63-79.

7. Alvarez RH, Valero V, Hortobagyi GN. Emerging targeted therapies for breast cancer. J Clin Oncol. 2010;28(20):3366-79.

8. Spridon D, Panaitescu L, Ursu D, Uglea CV. Synthesis and biocompatibility of maleic anhydride copolymers: 1. Maleic anhydridevinyl acetate, maleic anhydride-methyl methacrylate, and maleic anhydride-styrene. The Cambridge Polymer Conference: Partnership in Polymers, Cambridge, UK, 30 Sep-2 Oct 1996 Polym Int 1997; 43(2): 175-81.
9. Hoste K, Winne KD, Schacht E. Polymeric prodrug. Int J Pharm 2004; 277:119-31.

10.Karakus G, Zengin HB, Polat ZA, Yenidunya AF, Aydin S. Cytotoxicity of three maleic anhydride copolymers and common solvents used for polymer solvation. Polymer Bulletin. 2013; 70(5): 591-12.

11.Skehan P, Storeng R, Scudiero D, Monks A, McMahon J, Vistica D, Warren JT, Bokesch H, Kenney S, Boyd MR. New colorimetric cytotoxicity assay for anticancer-drug screening. J Natl Cancer Inst 1990; 82(13):1107.

12.Karakuş G, Malatyalı E, Zengin H, Değerli S. In vitro amoebicidal activity of poly(maleic anhydride-co-vinyl acetate) copolymer on Acanthamoeba spp. trophozoites and cysts. Basic Clin Sci 2013; 2: 1-14.

13.Chai F, Zhang L, Xiao X, Duan C, Huang Q, Fan C, Li J et al. Cucurbitacin B reverses multidrug resistance by targeting CIP2A to reactivate protein phosphatase $2 \mathrm{~A}$ in $\mathrm{MCF}-$ 7/adriamycin cells. Oncology Reports 2016; 36:1180-86. 